\title{
Penapisan Bakteri Endofit Akar Kedelai Secara in Planta untuk Mengendalikan Penyakit Pustul Bakteri
}

\section{Screening of Indigenous Bacterial Endophytes From Healthy Soybean Root to Control Bacterial Pustule Using in Planta Technique}

\author{
Trimurti Habazar*, Zurai Resti, Yulmira Yanti, Jumsu Trisno, Afrika Diana \\ Universitas Andalas, Padang 25163
}

\begin{abstract}
ABSTRAK
Bakteri endofit berada dalam jaringan tanaman tanpa menimbulkan gejala penyakit. Bakteri ini mampu mengendalikan patogen dan memacu pertumbuhan serta hasil tanaman. Penelitian bertujuan memperoleh isolat bakteri endofit yang mampu mengendalikan penyakit pustul bakteri dan meningkatkan pertumbuhan serta hasil kedelai. Penapisan isolat bakteri endofit dilakukan secara in planta untuk mengendalikan penyakit pustul bakteri. Isolat bakteri endofit diintroduksi 2 kali, yaitu pada benih kedelai $\left(10^{8} \mathrm{cfu} / \mathrm{mL}\right)$ dan setelah kedelai berumur 3 minggu. Tanaman berumur 4 minggu diinokulasi dengan Xanthomonas axonopodis pv. glycines melalui pelukaan daun. Peubah yang diamati ialah perkembangan penyakit pustul bakteri dan pertumbuhan tanaman serta jumlah polong kedelai. Isolat St4E1.1 dan St1E1.1. adalah bakteri endofit terbaik untuk mengendalikan penyakit pustul bakteri dan meningkatkan pertumbuhan dan polong kedelai.
\end{abstract}

Kata kunci: bakteri endofit, in planta, kedelai, penyakit pustul bakteri

\begin{abstract}
Endophytic bacteria reside within plant hosts without causing disease symptoms. Bacterial endophytes promote plant growth and yield, suppress pathogens, may help to remove contaminants, solubilize phosphate, or contribute assimilable nitrogen to plants. The aim of this study were to obtain indigenous endophytic bacterial isolates, which have the ability to control bacterial pustule cause by Xanthomonas axonopodis pv. glycines and to increase growth and yield of soybean. The bacterial endophyte isolates were introduced as seed treatment $\left(10^{8} \mathrm{cfu} / \mathrm{ml}\right)$ and soil drench on 3 weeks old soybean seedling. Xanthomonas axonopodis pv. glycines were inoculated on one month old of soybean by pricking leaf methodes. The effect of bacterial endophyte on disease incidence, disease severity, plant growth and yield of soybean were evaluated. We have found two selected bacterial endophyte isolates from soybean's rhizosphere (St4E1.1 and St1E1.1.), with the ability to control bacterial pustule and to increase growth and yield of soybean.
\end{abstract}

Key words: bacterial endophyte, bacterial pustule, in planta technique, soybean

\section{PENDAHULUAN}

Bakteri endofit berada dalam jaringan tanaman tanpa menimbulkan gejala penyakit
(Zinniel et al. 2002). Pengendalian patogen oleh bakteri endofit dapat melalui anticendawan atau antibakteri, siderofor, kompetisi terhadap nutrisi, menginduksi ketahanan tanaman

*Alamat penulis korespondensi: Fakultas Pertanian Universitas Andalas, Kampus Limau Manis, Padang 25163 Tel: 0751-7059087, Faks: 0751-72702, Surel: trimurtihabazar@yahoomail.com 
secara sistemis atau meningkatkan ketersediaan hara tanaman (Sturz et al. 2000; Sessitsch et al. 2004).

Bakteri endofit dapat mengendalikan penyakit hawar bakteri oleh Xanthomonas axonopodis pv. malvacearum pada kapas (Rajendran et al. 2006), menekan perbanyakan nematoda (Sturz dan Kimpinski 2004). Curtobacterium flaccumfaciens sebagai endofit pada tanaman jeruk mampu meningkatkan ketahanan jeruk terhadap Xylella fastidiosa (Araujo et al. 2002). Bakteri endofit dari kentang menunjukkan aktivitas antagonis terhadap cendawan (Sessitsch et al. 2004; Berg et al. 2005) dan menghambat perkembangan bakteri patogen dari genus Erwinia dan Xanthomonas (Sessitsch et al. 2004). Informasi mengenai bakteri endofit dari perakaran kedelai (indigenus) untuk pengendalian penyakit pustul bakteri masih terbatas.

Penyakit pustul bakteri disebabkan oleh Xanthomonas axonopodis pv. glycines. Bakteri ini merupakan salah satu penyebab penyakit utama pada tanaman kedelai di Indonesia. Penyakit pustul bakteri tergolong penting karena dapat menyebar melalui benih sampai 8\% (Prathuangwong dan Amnuaykit 1987). Beberapa galur Xag juga menyerang kacang panjang, Dolichos uniflorus, Glycine spp., Phaseolus lunatus, P. vulgaris (Garrity 2005).

Penelitian bertujuan memperoleh isolat bakteri endofit indigenus (BEI) yang efektif dalam pengendalian penyakit pustul bakteri dan peningkatan pertumbuhan serta hasil kedelai.

\section{BAHAN DAN METODE}

\section{Isolasi Bakteri Endofit dan Perbanyakannya}

Akar tanaman kedelai dari daerah endemik penyakit pustul bakteri (Nagari Sikabau, Kecamatan Sitiung, Kabupaten Dharmasraya, Sumatera Barat) berumur 2-3 bulan, telah berbuah dan sehat diisolasi bakteri endofitnya menggunakan medium agar-agar nutrien. Sebanyak $1 \mathrm{~g}$ akar dicuci dengan akuades dan direndam alkohol 70\% selama 1 menit, dibilas akuades steril dan dimaserasi. Suspensi akar diencerkan sampai $10^{-6}$ dan diisolasi bakterinya sampai diperoleh biakan murni pada medium agar-agar nutrien. Isolat yang dipilih ialah koloni dominan dengan morfologi yang berbeda. Isolat bakteri tersebut dipindahkan ke dalam tabung mikro berisi $1 \mathrm{~mL}$ akuades steril dan disimpan dalam lemari pendingin.

Isolat bakteri diremajakan pada medium agar-agar nutrien dan diinkubasi selama 48 jam. Biakan isolat disuspensikan dalam akuades steril untuk uji pada benih. Kepadatan populasi ditentukan berdasarkan pada perbandingan dengan larutan McFarland skala 8 (populasi bakteri $10^{8} \mathrm{sel} / \mathrm{mL}$ ). Perbanyakan isolat untuk uji tanaman dilakukan menggunakan medium nutrien cair. Sebanyak $25 \mathrm{~mL}$ medium dan satu koloni diinkubasi 18 jam pada alat pengocok horisontal pada kecepatan $150 \mathrm{rpm}$. Selanjutnya, $1 \mathrm{~mL}$ suspensi isolat dipindahkan ke dalam $150 \mathrm{~mL}$ medium cair nutrien dan diinkubasi 48 jam. Kepadatan populasi ditentukan populasinya dengan cara yang sama seperti untuk uji benih.

\section{Introduksi Bakteri Endofit dan Penanaman Kedelai}

Benih kedelai varietas Anjasmoro disterilkan dengan $\mathrm{NaOCl} 1 \%$ dicuci dengan akuades steril dan dikeringkan. Selanjutnya benih direndam dalam suspensi isolat bakteri selama 10 menit. Benih ditanam dalam pot dengan medium tanam campuran tanah steril dan pupuk kandang $(2: 1, \mathrm{v} / \mathrm{v})$. Introduksi bakteri endofit berikutnya ialah pada tanaman berumur 3 minggu dengan menyiramkan $10 \mathrm{~mL}$ suspensi bakteri pada tanah.

\section{Perbanyakan dan Inokulasi $X$. axonopodis pv. glycines}

Xanthomonas axonopodis pv. glycines diisolasi menggunakan medium agar-agar glukosa nutrien dari daun kedelai dengan gejala penyakit pustul bakteri dari daerah yang sama dengan sumber bakteri endofit. Isolat yang telah murni diidentifikasi berdasarkan pada sifat morfologi, fisiologi, reaksi hipersensitif, dan patogenisitasnya 
(Gambar 1). X. axonopodis pv. glycines diremajakan pada medium agar-agar glukosa nutrien selama 5 hari, lalu koloni bakteri disuspensikan dalam $9 \mathrm{~mL}$ akuades steril. Suspensi $X$. axonopodis pv. glycines yang digunakan ditentukan dengan cara yang sama seperti untuk uji benih. Sebanyak 3 daun muda dari tanaman yang berumur 50 hari, dilukai dan diinokulasi dengan mengolesnya, lalu tanaman diselubungi dengan plastik bening selama 5 hari.

Dalam penelitian ini setiap pot tanaman berumur 14 hari dipupuk $0.23 \mathrm{~g}$ urea, $0.30 \mathrm{~g}$ SP 36, dan $0.45 \mathrm{~g} \mathrm{KCl}$. Polong kedelai dipanen umur 88 hari.

Penelitian disusun dalam rancangan acak lengkap dengan 10 perlakuan dan 5 ulangan. Perlakuan yang diuji ialah 9 isolat BEI yang diintroduksi pada benih kedelai dan yang tidak diberi isolat BEI (kontrol). Data dianalisis dengan sidik ragam yang dilanjutkan dengan uji Duncan.

Peubah yang diamati ialah perkembangan penyakit pustul bakteri (masa inkubasi, persentase dan intensitas serangan pada daun dan polong), pertumbuhan tanaman (daya berkecambah, tinggi tanaman, jumlah daun, jumlah cabang, saat muncul bunga dan polong pertama, dan bobot biji). Efektivitas penggunaan isolat bakteri endofit untuk memperlambat masa inkubasi penyakit pustul bakteri, meningkatkan pertumbuhan tanaman dan bobot biji dihitung menggunakan rumus 1 , sedangkan efektivitas penggunaan isolat bakteri endofit dalam menurunkan persentase dan intensitas serangan penyakit pustul bakteri menggunakan rumus 2 .

$$
\begin{aligned}
& E=\frac{P-K}{K} \times 100 \% \\
& E=\frac{K-P}{K} \times 100 \%
\end{aligned}
$$

dengan: E, efektivitas; P, perlakuan; K, kontrol.

\section{HASIL}

\section{Perkembangan Penyakit Pustul Bakteri}

Hampir semua isolat bakteri endofit yang diinokulasikan pada tanaman kedelai mampu mengendalikan $X$. axonopodis pv. glycines (Tabel 1). Isolat ST2E1.2 memperlambat masa inkubasi $X$. axonopodis pv. glycines dengan efektivitas $30 \%$ jika dibandingkan dengan kontrol. Penyakit pustul bakteri yang rendah terjadi pada tanaman kedelai yang diinokulasi dengan ST4E2.1 dan ST4E1.1. Isolat tersebut mampu menurunkan intensitas serangan $X$. axonopodis pv. glycines dibandingkan dengan kontrol dan meningkatkan ketahanan. Isolat yang terbaik ialah ST4E1.1, ST2E1.2, dan ST1E5.2.

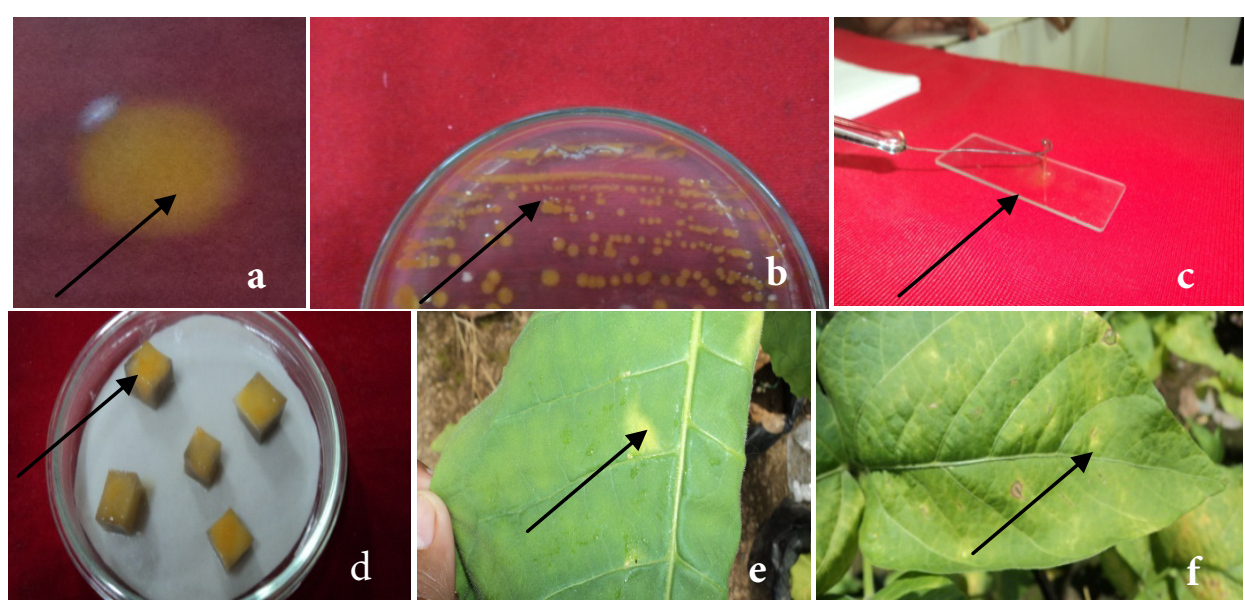

Gambar 1 Morfologi koloni, fisiologi, dan patogenisitas Xanthomonas axonopodis pv. glycines. a, bentuk koloni pada medium NGA ( 5 hsi); b, produksi pigmen Xanthomonadin; c, reaksi Gram negatif; d, produksi enzim pectinase; e, reaksi hipersensitif +; f, patogenisitas + pada daun kedelai. 


\section{Pertumbuhan dan Hasil Kedelai}

Daya berkecambah benih kedelai yang diinokulasi dengan 6 isolat bakteri endofit meningkat menjadi $100 \%$ dengan efektivitas $11.11 \%$ dibandingkan dengan kontrol (Tabel 2). Benihyang diinokulasi denganisolatbakteri endofit, daya berkecambahnya meningkat, sedangkan pada kontrol terjadi penurunan. Tinggi tanaman kedelai setelah diinokulasi dengan isolat bakteri endofit menunjukkan pengaruh yang tidak berbeda. Jumlah daun kedelai meningkat pada perlakuan isolat ST1E5.2 dan ST4E1.1. Jumlah cabang kedelai meningkat pada tanaman yang diinokulasi dengan isolat ST1E5.2 dan ST4E1.1.

Saat muncul bunga pada tanaman kedelai tidak dipengaruhi oleh isolat bakteri endofit (Tabel 3), demikian juga halnya dengan saat muncul polong pertama. Bobot basah dan kering biji kedelai terlihat meningkat pada

Tabel 1 Perkembangan penyakit pustul bakteri pada tanaman kedelai yang diberi perlakuan bakteri endofit pada hari ke-26 setelah inokulasi

\begin{tabular}{|c|c|c|c|c|c|c|c|}
\hline \multirow{2}{*}{ Isolat } & \multicolumn{2}{|c|}{ Masa inkubasi } & \multicolumn{2}{|c|}{ Persentase daun terserang } & \multicolumn{3}{|c|}{ Intensitas daun terserang } \\
\hline & Hari & $\begin{array}{c}\text { Efektivitas } \\
(\%)\end{array}$ & $\%$ & $\begin{array}{c}\text { Efektivitas } \\
(\%)\end{array}$ & $\%$ & $\begin{array}{c}\text { Efektivitas } \\
(\%)\end{array}$ & Reaksi \\
\hline Kontrol & $8.0 \mathrm{~d}$ & 0.0 & $26.8 \mathrm{ab}$ & 0.0 & $10.2 \mathrm{ab}$ & 0.00 & Agak tahan \\
\hline PL3E1.2 & $8.0 \mathrm{~d}$ & 0.0 & $32.8 \mathrm{a}$ & -22.4 & $11.8 \mathrm{a}$ & -15.7 & Agak tahan \\
\hline ST1E4.2 & $8.6 \mathrm{~cd}$ & 7.5 & $25.8 \mathrm{ab}$ & 3.7 & $9.6 \mathrm{abc}$ & 5.9 & Tahan \\
\hline ST1E3.1 & $9.2 \mathrm{bc}$ & 15.0 & $26.2 \mathrm{ab}$ & 2.2 & $9.6 \mathrm{abc}$ & 5.9 & Tahan \\
\hline ST2E2.2 & $9.6 \mathrm{ab}$ & 20.0 & $29.2 \mathrm{ab}$ & -9.0 & $10.0 \mathrm{abc}$ & 2.0 & Tahan \\
\hline ST1E5.2 & $9.2 \mathrm{bc}$ & 15.0 & $23.2 \mathrm{ab}$ & 13.4 & $7.6 \mathrm{abc}$ & 25.5 & Tahan \\
\hline ST4E2.1 & $9.0 \mathrm{bc}$ & 12.5 & $18.6 \mathrm{~b}$ & 30.6 & $8.0 \mathrm{abc}$ & 21.6 & Tahan \\
\hline ST2E1.2 & $10.4 \mathrm{a}$ & 30.0 & $28.6 \mathrm{ab}$ & -6.7 & $7.0 \mathrm{bc}$ & 31.4 & Tahan \\
\hline ST4E1.1 & $9.0 \mathrm{bc}$ & 12.5 & $19.4 \mathrm{~b}$ & 27.6 & $5.6 \mathrm{c}$ & 45.1 & Tahan \\
\hline ST1E1.1 & $9.4 \mathrm{bc}$ & 17.5 & $23.0 \mathrm{ab}$ & 14.2 & $8.2 \mathrm{abc}$ & 19.6 & Tahan \\
\hline $\begin{array}{l}\text { Koefisien } \\
\text { korelasi }\end{array}$ & 7.9 & & 40.8 & & 41 & & \\
\hline
\end{tabular}

Angka yang diikuti dengan huruf yang sama dalam satu kolom tidak berbeda nyata pada uji Duncan 5\%

Tabel 2 Pertumbuhan kedelai yang diberi perlakuan bakteri endofit pada hari ke-26 setelah inokulasi

\begin{tabular}{|c|c|c|c|c|c|c|c|c|}
\hline \multirow{2}{*}{ Isolat } & \multicolumn{2}{|c|}{$\begin{array}{c}\text { Daya kecambah } \\
\text { benih }\end{array}$} & \multicolumn{2}{|c|}{ Tinggi tanaman } & \multicolumn{2}{|c|}{ Jumlah daun } & \multicolumn{2}{|c|}{ Jumlah cabang } \\
\hline & $\%$ & $\begin{array}{c}\text { Efektivitas } \\
(\%)\end{array}$ & $\mathrm{cm}$ & $\begin{array}{c}\text { Efektivitas } \\
(\%)\end{array}$ & Helai & $\begin{array}{c}\text { Efektivitas } \\
(\%)\end{array}$ & Tangkai & $\begin{array}{c}\text { Efektivitas } \\
(\%)\end{array}$ \\
\hline Kontrol & 90 & 0.0 & 95.6 & 0.0 & $32.2 \mathrm{~b}$ & 0.0 & 5.6 & 0.0 \\
\hline PL3E1.2 & 100 & 11.1 & 97.2 & 6.4 & $33.2 \mathrm{~b}$ & 3.1 & 5.8 & 3.6 \\
\hline ST1E4.2 & 90 & 0.0 & 104.0 & 13.8 & $34.0 \mathrm{~b}$ & 5.6 & 5.8 & 3.6 \\
\hline ST1E3.1 & 90 & 0.0 & 97.0 & 6.1 & $34.8 \mathrm{~b}$ & 8.1 & 5.6 & 0.0 \\
\hline ST2E2.2 & 100 & 11.1 & 97.4 & 6.6 & $31.8 \mathrm{~b}$ & -1.2 & 6.2 & 10.7 \\
\hline ST1E5.2 & 100 & 11.1 & 97.8 & 7.0 & $40.8 \mathrm{a}$ & 26.7 & 6.6 & 17.9 \\
\hline ST4E2.1 & 100 & 11.1 & 95.2 & 4.2 & $36.8 \mathrm{ab}$ & 14.3 & 5.6 & 0.0 \\
\hline ST2E1.2 & 100 & 11.1 & 101.4 & 10.9 & $36.2 \mathrm{ab}$ & 12.4 & 6.2 & 10.7 \\
\hline ST4E1.1 & 100 & 11.1 & 94.6 & 3.5 & $39.8 \mathrm{a}$ & 23.6 & 6.6 & 17.9 \\
\hline ST1E1.1 & 100 & 11.1 & 98.0 & 7.2 & $33.4 \mathrm{~b}$ & 3.7 & 6.0 & 7.1 \\
\hline
\end{tabular}

Angka yang diikuti dengan huruf yang sama dalam satu kolom tidak berbeda nyata pada uji Duncan 5\% 
Tabel 3 Perkembangan fase generatif dan hasil kedelai yang diberi perlakuan bakteri endofit

\begin{tabular}{|c|c|c|c|c|c|c|c|c|}
\hline \multirow{3}{*}{ Isolat } & \multirow{2}{*}{\multicolumn{2}{|c|}{$\begin{array}{c}\text { Saat muncul bunga } \\
\text { pertama }\end{array}$}} & \multirow{2}{*}{\multicolumn{2}{|c|}{$\begin{array}{l}\text { Saat muncul polong } \\
\text { pertama }\end{array}$}} & \multicolumn{4}{|c|}{ Bobot biji/tanaman } \\
\hline & & & & & \multicolumn{2}{|c|}{ Basah } & \multicolumn{2}{|c|}{ Kering } \\
\hline & Hst & $\begin{array}{c}\text { Efektivitas } \\
(\%)\end{array}$ & Hst & $\begin{array}{c}\text { Efektivitas } \\
(\%)\end{array}$ & $\mathrm{g}$ & $\begin{array}{c}\text { Efektivitas } \\
(\%)\end{array}$ & $\mathrm{g}$ & $\begin{array}{c}\text { Efektivitas } \\
(\%)\end{array}$ \\
\hline Kontrol & $33.2 \mathrm{ab}$ & 0.0 & $47.6 \mathrm{abc}$ & 0.0 & $40.9 \mathrm{ab}$ & 0.0 & 28.9 & 0.00 \\
\hline PL3E1.2 & $33.2 \mathrm{ab}$ & 0.0 & $47.6 \mathrm{abc}$ & 0.0 & $40.3 \mathrm{ab}$ & -2.0 & 25.5 & -11.73 \\
\hline ST1E4.2 & $33.4 \mathrm{ab}$ & -0.1 & $47.6 \mathrm{abc}$ & 0.0 & $36.5 \mathrm{ab}$ & -10.9 & 28.4 & -1.94 \\
\hline ST1E3.1 & $33.4 \mathrm{ab}$ & -0.1 & $47.8 \mathrm{ab}$ & -0.4 & $42.0 \mathrm{ab}$ & 2.7 & 27.1 & -6.23 \\
\hline ST2E2.2 & $33.2 \mathrm{ab}$ & 0.0 & $48.2 \mathrm{a}$ & -1.3 & $37.3 \mathrm{ab}$ & -8.8 & 29.2 & 0.93 \\
\hline ST1E5.2 & $33.0 \mathrm{ab}$ & 0.1 & $46.6 \mathrm{bcd}$ & 2.1 & $41.8 \mathrm{ab}$ & 2.1 & 25.6 & -11.35 \\
\hline ST4E2.1 & $33.4 \mathrm{ab}$ & -0.1 & $46.0 \mathrm{~d}$ & 3.4 & $40.5 \mathrm{ab}$ & -1.1 & 25.1 & -13.25 \\
\hline ST2E1.2 & $32.6 \mathrm{~b}$ & 1.8 & $46.2 \mathrm{~d}$ & 2.9 & $32.1 \mathrm{~b}$ & -21.6 & 32.1 & 11.17 \\
\hline ST4E1.1 & $33.2 \mathrm{ab}$ & 0.0 & $46.6 \mathrm{bcd}$ & 2.1 & $45.9 \mathrm{a}$ & 12.7 & 34.6 & 19.75 \\
\hline ST1E1.1 & $33.4 \mathrm{ab}$ & -0.1 & $46.4 \mathrm{~cd}$ & 2.5 & $43.6 \mathrm{ab}$ & 6.6 & 34.4 & 18.89 \\
\hline $\begin{array}{l}\text { Koefisien } \\
\text { korelasi }\end{array}$ & 2.1 & & 2.3 & & 25.7 & & & \\
\hline
\end{tabular}

Angka yang diikuti dengan huruf yang sama dalam satu kolom tidak berbeda nyata pada uji Duncan 5\%

tanaman yang diinokulasi dengan isolat bakteri endofit ST4E1.1 dan ST1E1.1.

\section{PEMBAHASAN}

Hampir semua isolat bakteri endofit yang diinokulasi pada kedelai mampu meningkatkan ketahanan tanaman terhadap penyakit pustul bakteri dari kategori agak tahan (kontrol) menjadi tahan. Kedelai yang diinokulasi dengan isolat ST4E1.1 menunjukkan intensitas serangan $X$. axonopodis $\mathrm{pv}$. glycines yang paling rendah $(5.6 \%)$ dengan efektivitas $45.09 \%$. Hasil penelitian ini menunjukkan bahwa isolat bakteri endofit mampu menghambat perkembangan $X$. axonopodis pv. glycines pada kedelai. Hasil yang sama dilaporkan beberapa peneliti, antara lain Curtobacterium flaccumfaciens meningkatkan ketahanan jeruk terhadap Xylella fastidiosa (Araujo et al. 2002), beberapa bakteri endofit menghambat perkembangan bakteri patogen Erwinia dan Xanthomonas pada kentang (Sessitsch et al. 2004), menekan perbanyakan nematoda pada kentang (Sturz dan Kimpinski 2004), mengendalikan penyakit hawar bakteri oleh $X$. axonopodis pv. malvacearum pada kapas (Rajendran et al. 2006).
Kemampuan isolat bakteri endofit untuk mengendalikan penyakit pustul bakteri diduga berkaitan dengan aktivitas induce systemic resistance (ISR) atau menginduksi ketahanan tanaman secara sistemik karena aplikasinya pada benih dan tanah, sedangkan penyakit pustul bakteri berkembang pada daun dan polong (filoplan). Bakteri endofit dilaporkan menunjukkan aktivitas ISR (Compant et al. 2005). ISR dapat dipicu oleh Pseudomonas fluorescens EP1 terhadap penyakit busuk merah oleh Colletotrichum falcatum pada tebu (Viswanathan dan Samiyappan 1999), Burkholderia phytofirmans PsJN terhadap Botrytis cinerea pada anggur (Ait Barka et al. 2000, 2002), dan Verticllium dahliae pada tomat (Sharma dan Nowak 1998), $P$. denitrificans 1-15 dan $P$. putida 5-48 terhadap Ceratocystis fagacearum pada oak (Brooks et al. 1994), P. fluorescens 63-28 terhadap Fusarium oxysporum f. sp. radicislycopersici pada tomat (M'Piga et al. 1997), Pythium ultimum dan F. oxysporum f. sp. pisi pada perakaran ercis (Benhamou et al. 1996a), Bacillus pumilus SE34 terhadap $F$. oxysporum f. sp. pisi pada akar kacang polong (Benhamou et al. 1996b) dan F. oxysporum f. sp. vasinfectum pada akar kapas (Conn et al. 1997). Namun informasi tentang peranan 
bakteri endofit dalam pengendalian penyakit oleh bakteri masih terbatas.

Beberapa hasil penelitian menunjukkan bahwa bakteri endofit mampu meningkatkan hasil tanaman (Rosenblueth dan MartínezRomer 2006). Hubungan antara tanaman dan bakteri endofit merupakan interaksi secara tertutup, dalam hal ini tanaman menyediakan nutrien untuk bakteri endofit dan bakteri endofit meningkatkan pertumbuhan dan kesehatan tanaman (Hallmann 1999). Terjadinya peningkatan penyerapan nutrisi tanaman oleh bakteri endofit, karena mampu melarutkan fosfat dan juga berpartisipasi dalam asimilasi fosfat (Kuklinsky-Sobral et al. 2004).

Berdasarkan hasil penelitian ini dapat disimpulkan bahwa isolat ST1E1.2, ST4E2.1, ST4E1.1, dan ST1E5.2 mampu meningkatkan ketahanan kedelai terhadap penyakit pustul bakteri dan meningkatkan pertumbuhan serta hasil. Bakteri endofit isolat ST4E1.1 adalah yang terbaik.

\section{UCAPAN TERIMA KASIH}

Penelitian ini dibiayai oleh DP2M DIKTI Depdiknas melalui Hibah Kompetensi Tahun 2010 dengan Kontrak No. 429/SP2H/PP/ DP2M/VI/2010 tgl. 11 Juni 2010.

\section{DAFTAR PUSTAKA}

Ait Barka E, Belarbi A, Hachet C, Nowak J, Audran JC. 2000. Enhancement of in vitro growth and resistance to gray mould of Vitis vinifera cocultured with plant growth-promoting rhizobacteria. FEMS Microbiol Lett. 186(5):91-95.

Ait Barka E, Gognies S, Nowak J, Audran JC, Belarbi A. 2002. Inhibitory effect of endophyte bacteria on Botrytis cinerea and its influence to promote the grapevine growth. Biol Control. 24(2):135-142. doi: 10.1016/S1049-9644(02)00034-8.

Araujo WL, Marcon J, Maccheroni WJr, Van Elsas JD, Van Vuurde JWL, Azevedo JL. 2002. Diversity of endophytic bacterial populations and their interaction with Xylella fastidiosa in citrus plants. Appl Environ Microbiol. 68(10):49064914. doi: 10.1128/AEM.68.10.49064914.2002.

Benhamou N, Belanger RR, and Paulitz TC. 1996a. Induction of differential host responses by Pseudomonas fluorescens in Ri T-DNA-transformed pea roots after challenge with Fusarium oxysporum f. sp. pisi and Pythium ultimum. Phytopathology. 86(11):1174-1185. doi: 10.1094/Phyto-86-1174.

Benhamou N, Kloepper JW, Quadt-Hallmann A, Tuzun S. 1996b. Induction of defenserelated ultrastructural modifications in pea root tissues inoculated with endophytic bacteria. Plant Physiol. 112(3):919-929. doi: 10.1104/pp.112.3.919.

Berg G, Krechel A, Ditz M, Sikora RA, Ulrich A, Hallmann J. 2005. Endophytic and ectophytic potato-associated bacterial communities differ in structure and antagonistic function against plant pathogenic fungi. FEMS Microbiol Ecol. 51(2):215-229.

Brooks DS, Gonzalez CF, Apple DN, and Filer, TH. 1994. Evaluation of endophytic bacteria as potential biological control agents for oak wilt. Biol Control. 4:373381.

Compant S, Duffy B, Nowak J, Cle'ment C, Barka EA. 2005. Use of plant growthpromoting bacteria for biocontrol of plant diseases: Principles, mechanisms of action, and future prospects. Appl Environ Microbiol. 71(9):4951-4959. doi: 10.1128/AEM.71.9.4951-4959.2005.

Conn KL, Nowak J, Lazarovits G. 1997. A gnotobiotic bioassay for studying interactions between potato and plant growth-promoting rhizobacteria. Can J Microbiol. 43(9):801-808. doi: 10.1139/ m97-117.

Garrity GM. 2005. Bergey's manual of sistematic bacteriology. Second Edition. Volume Two: The proteobacteria. Part $B$ gammaproteobacteria. Michigan (US): State Univ. 
Hallmann J. 1999. Plant interactions with endophytic bacteria. http://www.bspp. org.uk/ archives/bspp1999/session3.php. [diakses 21 Juli 2011].

Kuklinsky-Sobral J, Araujo WL, Mendes R, Geraldi IO, Pizzirani- Kleiner AA, and Azevedo, JL. 2004. Isolation and characterization of soybean-associated bacteria and their potential for plant growth promotion. Environ Microbiol. 6:1244-1251.

M'Piga P, Belanger RR, Paulitz TC, Benhamou N. 1997. Increased resistance to Fusarium oxysporum f. sp. radicislycopersici in tomato plants treated with the endophytic bacterium Pseudomonas fluorescens strain 63-28. Physiol Mol Plant Pathol. 50(5):301-320.

Prathuangwong S, Amnuaykit K. 1987. Studies on tolerance and rate reducing bacterial pustule of soybean cultivars/ lines. Kasetsart J. 21(4):408-420.

Rajendran L, Saravanakumar D, Ragunchander T, Samiyappan R. 2006. Endophytic bacterial induction of defence enzymes againts bacterial blight of cotton. Phytopathol Mediterr. 45(3):203-214.

Rosenblueth M, Martínez-Romero E. 2006. Bacterial endophytes and their interactions with hosts. MPMI. 19(8):827-836.

Sessitsch A, Reiter B, Berg G. 2004. Endophytic bacterial communities of field-grown potato plants and their plant- growth-promoting and antagonistic abilities. Can J Microbiol. 50(4):239-249.

Sharma VK, Nowak J. 1998. Enhancement of Verticillium wilt resistance in tomato transplants by in vitro coculture of seedlings with a plant growth-promoting rhizobacterium (Pseudomonas sp. strain PsJN). Can J Microbiol. 44:528-536.

Sturz A V, Christie BR, and Nowak J. 2000. Bacterial endophytes: Potential role in developing sustainable systems of crop production. Crit Rev Plant Sci. 19(1):130. doi: 10.1080/07352680091139169.

Sturz A, Kimpinski J. 2004. Endoroot bacteria derived from marigolds (Tagetes spp.) can decrease soil population densities of root-lesion nematodes in the potato root zone. Plant Soil. 262(1-2):241-249. doi: 10.1023/B:PLSO.0000037046.86670.a3.

Viswanathan R, Samiyappan R. 1999. Induction of systemic resistance by plant growth-promoting rhizobacteria against red rot disease in sugarcane. Sugar Tech. 1(3):67-76. doi: 10.1007/BF02945166.

Zinniel DK, Lambrecht P, Beth Harris N, Feng Z, Kuczmarski D, Higley P, Ishimaru CA, Arunakumari A, Barletta RG, Vidaver AK. 2002. Isolation and characterization of endophytic colonizing bacteria from agronomic crops and prairie plants. Appl Environ Microbiol. 68(5):2198-2208. 